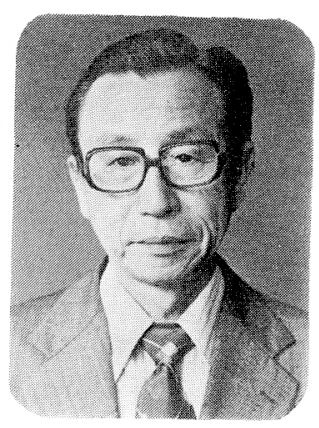

1.はじめに

変形に拈いて高温といらのは一般には $T / T_{m}\left(T, T_{m}\right.$ はそれぞれ絶対温度で表わした变形温度と融点) $\geq 0.5$ の温度領域を意味する。この温度では変形による加工硬 化之同時に回復が执こり加工硬化の一部，西るいは全部 が相殺されるのが特徵である。

本稿では高温変形の 1 つである高温クリープ変形扣よ びそのときに現われる結晶粒界すべりについて, 転位学 動との関連に扔いてわれわれの研究室で得られな成果を 中心に述べていきたい.

\section{2. 高温クリープ変形と転位挙動}

(1) 高温クリープ変形

高温クリープでは 1 次(せん移), 2 次 (定常), 3 次 (加 速)クリープの3 段階学経て破断にいたる(1). とのうち とくに定常クリープについての研究が古くから多く行わ れている。

これらの結果をまとめると定常クリープ速度, $\dot{\varepsilon}_{S}$, は

$$
\dot{\varepsilon}_{S} \propto\left(\sigma_{c} / E\right)^{n} \exp \left(-Q_{c} / R T\right)
$$

で表示できる場合が多い。ここで $\sigma_{c}$ はクリープ応力, Eはヤング率，Rはガス定数である， $Q_{c}$ はクリープの 活性化エネルギーと呼ばれ，多くの金属・合金で㧓散の 活性化エネルギー， $Q_{d}$ ， 等しいことが確かめられてい る(1)。このことは高温クリープ恋形に原子の拡散が何ら かの形で関与していることを示唆するが，これからだけ ではとれ以上のことはわからない。

一方 $n$ は応力指数と呼ばれるもので, ある種の合金で は3 近い值をとり，純金属やある種の合金では５岁る いはとれより大きい值をとることが知られている(2)。こ

***東北大学教授; 工学部金属材料工学科

* 第 24 回本多記念講演( 昭和 54 年 4 月 4 日, 東京, 東京大学)

Deformation and Dislocation Behaviour in Metals at Elevated Temperatures; Seiichi Karashima (Department of Materials Science, Faculty of Engineering, Tohoku University, Sendai) 1979 年 4 月 25 日受理
れはクリープ変形の律速機構を反映しているものとして それぞれI型，II型の合金という語が用いられることが 多い(3)。しかしあとで述べるよう同一合金でもクリー プ条件によってnの值が変ることがあるので，これは クリープ挙動の分類であると考孚た方がよい(4)。すなわ ち，雲用気を引きずる転位の粘性運動(5)〜 (7)あるいは回

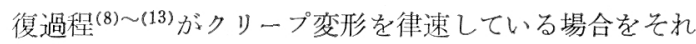
ぞれI型，II型といらことにする。

われわれを含めて多くの研究者によってI， II型の上 記以外の特徵的挙動が明らかにされ, 老れに従ってI, II型を判別する種々の方法が提案されている。以下それ らについて順を追ってみていこう。

\section{(2) 瞬間塑性ひずみおよび1次クリープ曲線}

金属材料に応力が加壳られると一航には僢間塑性ひず タが生じ，その後時間に依存するクリープ変形が進行す る。しかし図1に示すように，瞬間塑性ひずみが主とん ど現われないことが市る(14)。これが工型の特徵の1つ である。

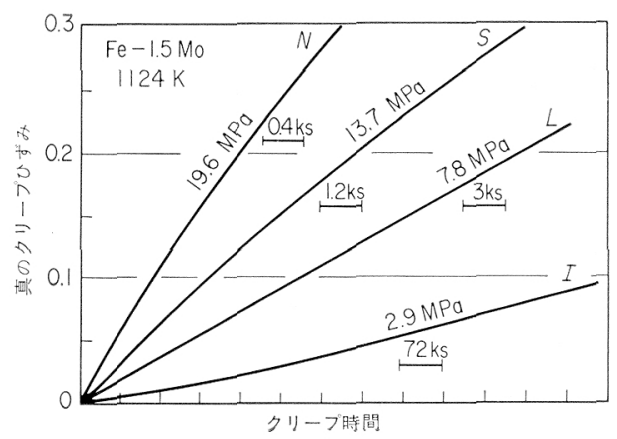

図 $1 \mathrm{Fe}-1.5 \mathrm{at} \% \mathrm{M}$ o 合金の 1 次クリープ曲線 ${ }^{(14)}$.

つぎに 1 次クリープ曲線であるが，金属・合金の種類 やクリープ条件によって種々の形状を示す。すなわら図 $19 \mathrm{Fe}-1.5 \mathrm{at} \% \mathrm{Mo}$ 合金の例では応力が大きくなる に従って 1 次クリープは逆せ九移型 (I 型), 直線型( L 型), $S$ 字型 ( $\mathrm{S}$ 型), さらには通常型 ( $\mathrm{N}$ 型)へと変化して いる。この上うに通常型以外の 1 次のクリープが現われ 


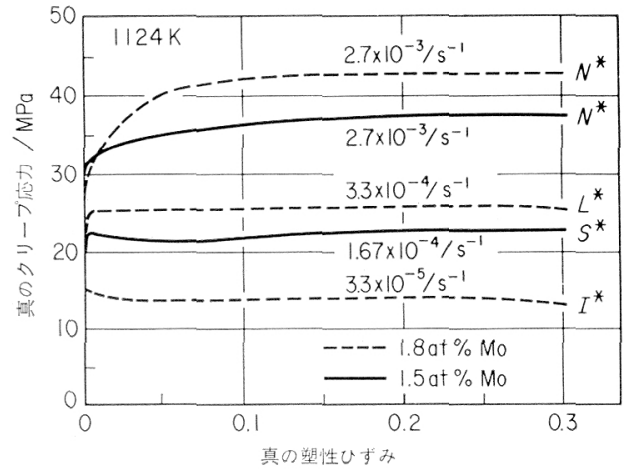

図 $2 \mathrm{Fe}-1.5$ at $\% \mathrm{Mo}, \mathrm{Fe}-1.8 \mathrm{at} \% \mathrm{Mo}$ 合金の引張 り試験による応力ーひずみ曲線 ${ }^{(14)}$.

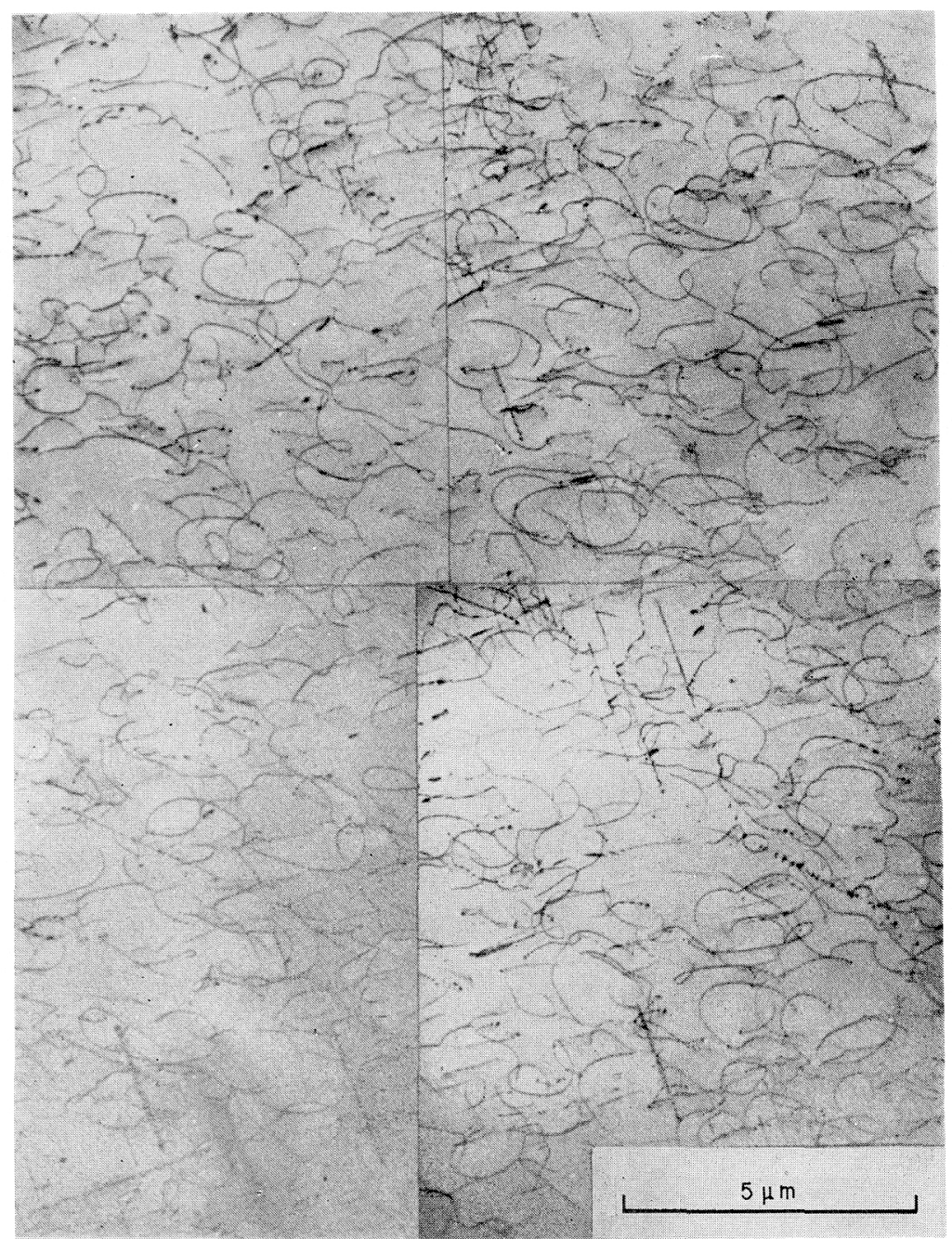

写真1 A1-5.5 at\% Mg 合金の定常クリープ段階での転位組織 ${ }^{(17)}$.
プの I,L, S, N 型に対応して I*, L*, S*, N*型の挙動がみ られる(14)。したがって引張り試験によっても I， II 型 の判別ができることになる。

このように両試験の結果がよく対応することは，I型 では転位が粘性運動をしていること，転位の運動を妨げ る内部応力が転位密度の平方根飞比例するけことを考慮 すると説明できるが，くわしいことは原論交 ${ }^{(14)}$ に譲る こととする。

\section{(3) 転 位組 織}

I，II型の場合の転位組織の特長を述べると，I型で は転位は均一分布をとる(17)のに対して, II型の場合に はセルあるいはサブグレイン†† が形成される(18)。

まずI型の典型例である $\mathrm{A} 1$ $5.5 \mathrm{at} \% \mathrm{Mg}$ 合金では写真1 か らもわかるように, 定常クリ 一プに入っても転位は均一に分 布している(17)。この場合全転 位が連動転位と考光られるが， 全転位密度とクリープ速度をク リープひずみに刘して示した図 3からもわかるように，1次ク リープ中の両者の変化がよく対 応している(19).

つぎにII型の代表例として銅 単絬晶での結果 ${ }^{(20)}$ を述べる。 初転位密度が $10^{8} / \mathrm{m}^{2}$ 程度の単 一すべり方位の銅単結晶をクリ ープ変形させ, ひずみの各段階 で試料表面で蚂る(111)面に転 位ピットをつくって観察した結 果の一例を写真 2 亿示す。これ は同一視野を示するのである が, 1次クリープ初期の組織 (写真 $2(\mathrm{a})$ ) は低温変形の組織 と本質的に異なるところはな く，小さいせルが形成されてい る $\mathrm{A}$ 領域と, 大きいセルが形成 されているB領域が，すべり線 に垂直に数百 $\mu \mathrm{m}$ の間隔で交互 に現われている。両領域での組 織はクリープひずみと共に変化
るのが工型の特徴で，温度が低く(15)，㐫力が低い(16)注 どこの挙動が現われ易い。

一方, 高温引張り試験に持ける応力ーひずみ曲線の初 期の様子をみると，図2から明らかなように1次クリ一
† 2. (3)で述べるように転位は均一分布をとるため, 連動転位は平均転位間隔に逆比例, 寸なわち転位 密度の平方根に比例する内部応力を受けることに なる。

† 以後两者をセルと総称する。 


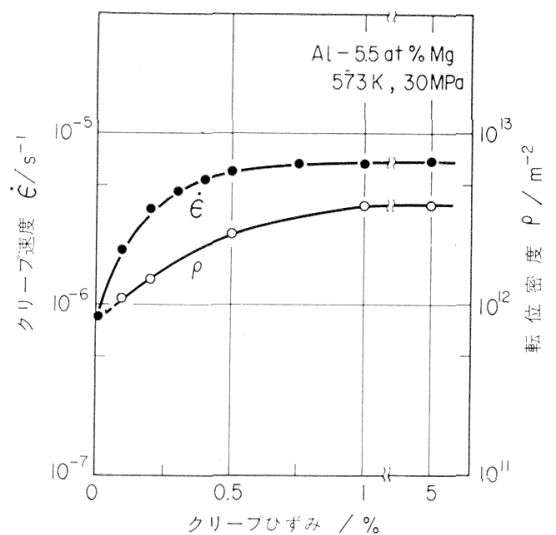

図 $3 \mathrm{~A} 1-5.5 \mathrm{at} \% \mathrm{Mg}$ 合金の 1 次クリープに特故 るクリープ速度, 転位密度のクリープひずみ 依存性 ${ }^{(19)}$ 。

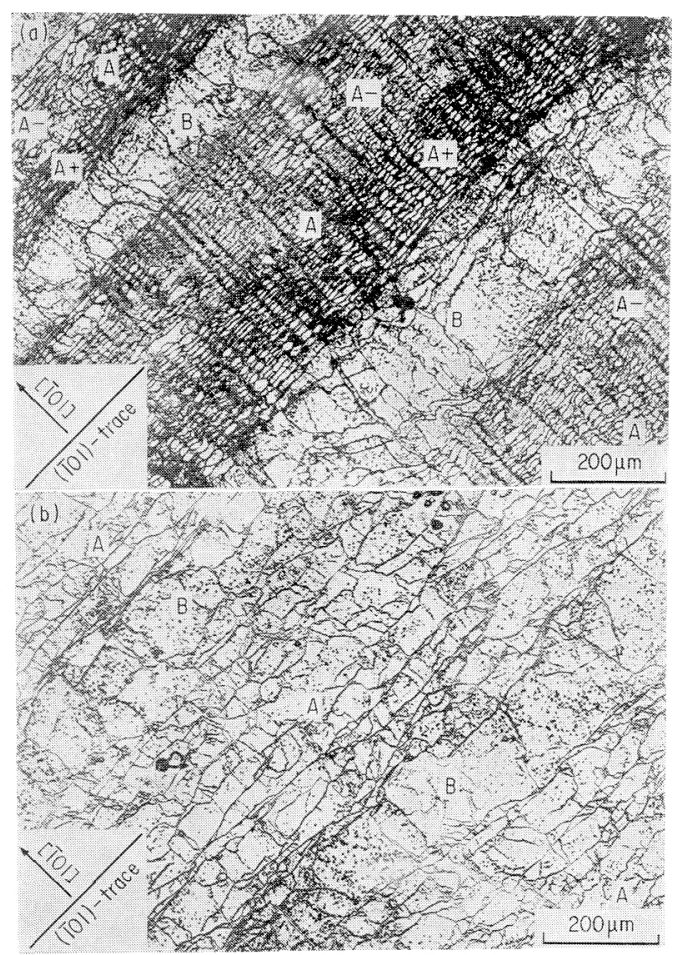

写真 2 銅単結晶をクリープ変形させたときの転位 組織 ${ }^{(20)}$. (a) 1 次クリープ初期, (b) 定常ク リープ.

して定常段階では写真 2 (b)のようにA, B 両領域が核 とえど区別できないよらになった。

図 4 はすべり線に平行な方向にはかった両領域でのセ ルの大き学，図 5 は両領域の平均クリープ速度けをそ れどれクリープひずみに対して示したものである。これ

† A, B 両領域の境界に微小硬度計によって区痕を つけ，その間の長さ変化をクリープ恃間で割った ものを平均クリープ速度とした。

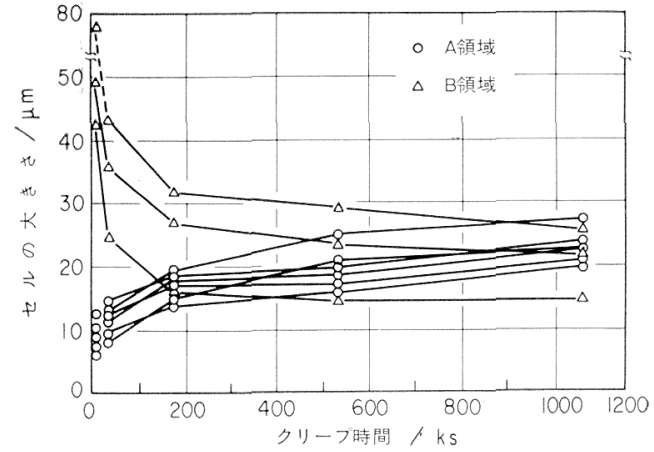

図4 銅単結晶の高温クリープ変形に和活るセルの 大きさの変化 ${ }^{(20)}$ 。

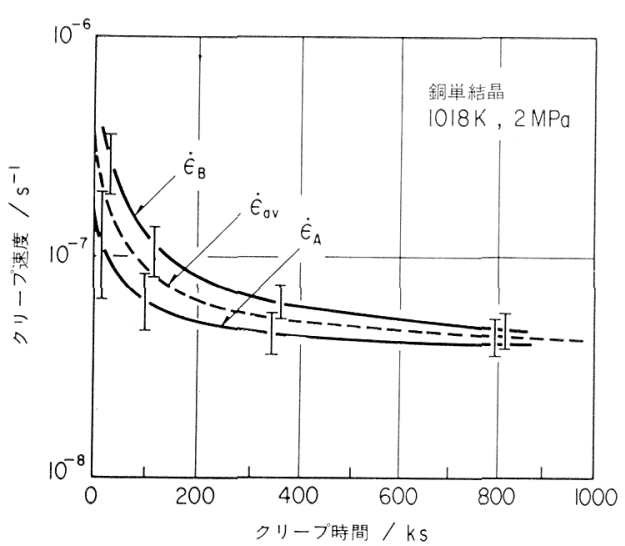

図 5 銅単結晶の高温クリープ変形に打战る $\mathrm{A}, \mathrm{B}$ 両領域の平均クリープ速度 ${ }^{(20)}\left(\dot{\varepsilon}_{\mathrm{A}}, \dot{\varepsilon}_{\mathrm{B}}\right.$ 打よび

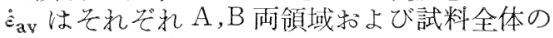
クリープ速度)。

らの結果はクリープ速度が転位構造に密接に関連するこ とを示唆するもので興味深い.

一方， $\alpha$ 鉄多結晶体で図6のよ5に全転位密度, $\rho_{\text {total }}$ およびセル壁けや内の転位密度， $\rho_{\mathrm{SB}}$, はクリープひずみと 共に增加して定常段階で一定值となるのに対して，七ル 内の転位密度， $\rho_{\mathrm{SG}}$ ， は定常段階屯で減少しつづする(21) ことが報告されている。この場合も運動転位密度と考光

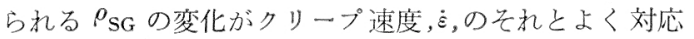
していることがわかる。われわれも銅単結晶で同様の結 果を得ている(22)。

\section{（4）Ｉ，II 型挙動と転位}

以上述べてきたことからI，II型クリーブ挙動に和け る転位のふるまいはつぎのように理解される。

束ず型では転位は雾国気を引きずる粘性運動を行い その速度は小さいため，応力によつて運動を開始した転 位も急には增殖されない。したがって瞬間塑性ひずみが

† セル女るいはサブグレイン組織に拉いて，転位が 密集している部分をセル壁と総称する。 


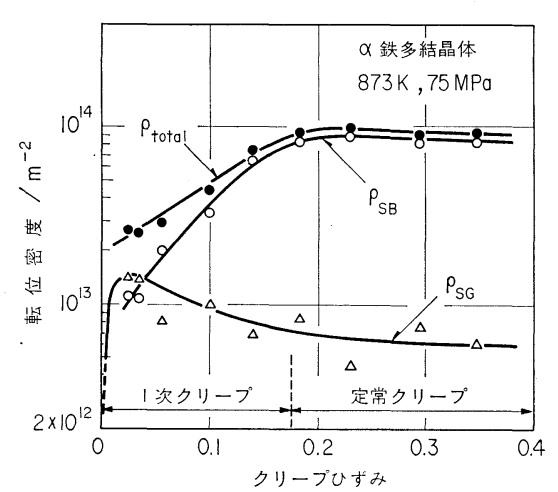

図6 $\alpha$ 鉄多結晶体に和ける転位密度のクリープひ ずみ依存性 ${ }^{(21)}$.

ほとんど扣こらない。また運動転位が障害にとめられて もとこに後続転位がきてもつれを生ずることも少なく， 転位は均一分布をとると考兄られる。変形が進むと転位 増殖によって転位密度が増加し，それだけクリープ速度 も大きくなって逆せん移型 1 次クリーブ挙動を示す。し か乙転位密度の増加は転位平均間隔の減少を通して内部 応力, $\sigma_{i}$ ，の増加 (加工硬化)をもたらす。一方転位平均間 隔の減少は転位の合一消減速度を大きくし，そのため回 復が促進されることになる。そして両者のつり合いとし て定常クリープが出現する.

つぎに型では転位は自由飛行運動をするものと考觉 られて打り, 運動速度が極めて大きいため応力付加直後 の転位增殖も速く行われ，かなりの瞬間塑性ひずみが生 ずる，その間形成されたセル組織は 1 次クリープ中に発 達し，それに応じて運動転位が減少する。またあとから わかるようにセル壁形成によって $\sigma_{i}$ が大きくなって， その結果としてクリープ速度がだんだん小さくなる通常 型 1 次クリープが現われる.

クリープの進行と共に加工硬化が大きくなる反面, 七 ル壁内での平均転位間隔の減少は転位の合一消減を促 し，そのため一轠規則正しい転位配列へと変化すると共 に平均転位間隔も増し，またセル壁の移動による整理統 合が行われるなどの回復過程が同時に進行して, それら 加工硬化，回復のバランスとして定常クリープが現われ る.

ところでセルが形成される場合 $\alpha$ 鉄単結晶の結 果 ${ }^{(23)(24)}$ からもわかるように, 七ル内の転位密度 $\propto \sigma_{c}$, セルの大きさ $\propto \sigma_{c}{ }^{-1}$, 七ル壁内の平均転位間隔 $\propto \sigma_{c}{ }^{-1}$ といずれもクリーブ応力， $\sigma_{c}$ ，に依存するが, 温度にはほ とんど無関係である。

\section{(5) 内部応力}

転位の運動を妨げる $\sigma_{i}$ の大小も I, II 型判別の 1 つ の基準となる(25)。一般に $\sigma_{i}$ の測定 ${ }^{(26)}$ には現在では stress transient dip test†が用いられるが, そのうち でも外插法 ${ }^{(27)}$ がもっとも信頼できる $\sigma_{i}$ の值を与えるも のとされている。

図 7 は $\alpha$ 鉄, $\mathrm{Fe}-3.5$ at\% Mo 合金での実測例†で, 図中に引いた曲線が縦軸と交わるところが $\sigma_{i} / \sigma$ の值を 示す(28). $\alpha$ 鉄ではその比がほぼ 1 に等しく开型の特徴 をよく示しているのに対して, Fe-Mo 合金ではその比 が 1 より小さく転位にはたらく有効応力が無視できない 工型の特徵がみられる。

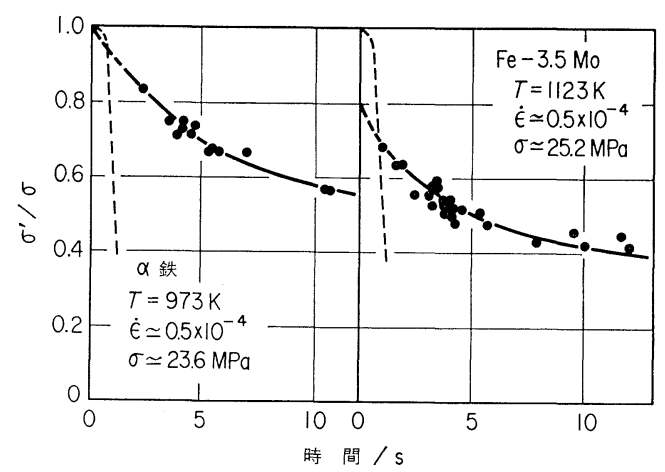

図7 stress transient dip test に打ける変形停 滞終了時間と dip した応力レベル， $\sigma^{\prime}$, と変 形応力, $\sigma$, との比の関係 ${ }^{(28)}$.

つぎに $\sigma_{i}$ がセル組織に密接に関連することを明らか にした $\mathrm{Cu}-\mathrm{A} 1$ 合金の結果 ${ }^{(15)}$ を述べる。この合金はアル ミニウム含有量が大きくなるほど S 字型の 1 次クリープ 曲線を示し易い， $\mathrm{Cu}-16$ at\% $\mathrm{A} 1$ 合金の場合も図 8 (a) からわかるよらに S 字型 1 次クリープを示し, I型であ ると考えられるにもかかわらずセル組織を形成するもの で例としてはあまりよくないものであるが，内部応力に ついての情報を与えてくれるものとして紹介して拉く.

図 8 (b)から文が増大寸る領域では転位は均一に分布 しており $\rho_{\text {total }}$ も增加するが, 永が減少し始める頃から セルが形成され運動転位と考えられるセル内の転位密 度††が急減することがわかる，それと同時に $\sigma_{i}$ は急に 大きくなる(図8 (c)) †††。 これらの結果から, 七ル組 織の形成は運動転位密度の減少と $\sigma_{i}$ の発生との相乗作 用を及ぼして字を減少させているものと結論される。

† 適当な日本語がないので原語のままにしておく。

十 高温引張りによる定常変形(これは定常クリープ 変形に対応すると考壳られている)中での測定で ある。

†† 図ではセル内の転位の長さ, $L_{c e l 1}$, の全転位の長

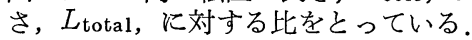

†ி この実験が行われた頃には前述の外插法が提案さ れていなかったので,この結果は通常の stress transient dip test(26)によって得られたものであ る. したがって $\sigma_{i} / \sigma_{c}$ の值そのものには問題があ るかも知れないが，七ル形成と同時に $\sigma_{i}$ が急に 大きくなることはまちがいがないと思われる。 


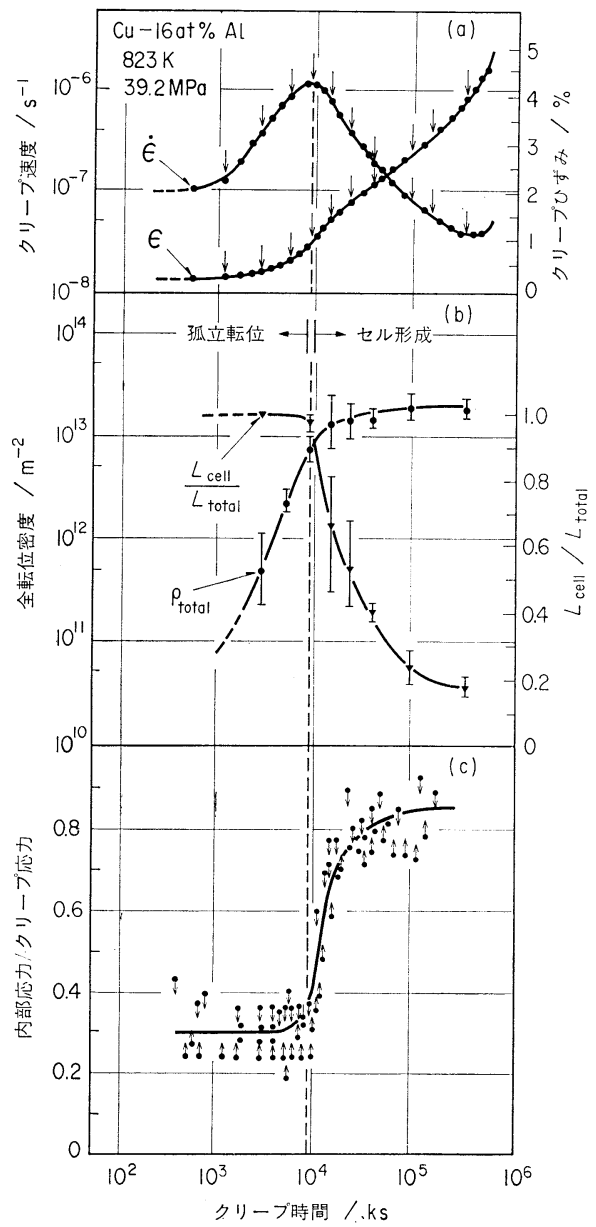

図 $8 \mathrm{Cu}-16 \mathrm{at} \% \mathrm{~A} 1$ 合金のクリープ变形中の諸パ ラメーターのクリープ時間に対する変化 ${ }^{(15)}$.

ところで2.(3) の終りのところで述べたセル組織を評

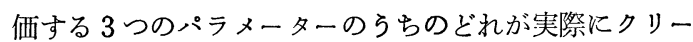
プ速度をきめているのかを知るため, Cu-0.56 at\% A1 合 金けにあらかじめ室温で種々の前ひずみを与えて異なっ たセル組織をつくっておき，これをクリープ温度より少 し高い温度で加熱してその組織を安定化したのちクリ一 プ試験を行った ${ }^{(29)}$. その結果によると, 定常クリープあ るいは最小クリープ速度以降の段階でのクリープ 組織 は，前ひずみを与えたときの組織と比較したときセルの 大きさには変化がなく，七ル壁内の平均転位間隔, $l_{0}$, が 変化しているだけであることがわかった. そして $\sigma_{i} \propto 1 / l_{0}$ であると同時に，定常クリープ速度あるいは最小クリ ープ速度も図 9 のように $1 / l_{0}$ に比例することが確かめ られた。これはセル組織がセル壁内の平均転位間隔によ ってきめられる内部応力を通して, クリープ変形に対す る抵抗に寄与していることを示唆するものであろう.

† アルミニウムを僅か添加したのは, クリープ中の 再結晶を防ぐためである。

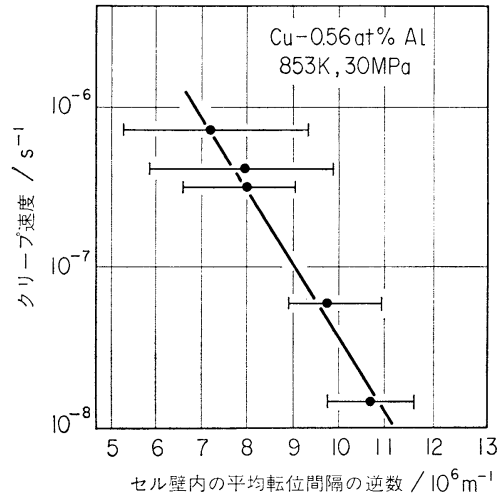

図 9 種々の前ひずみを与えた $\mathrm{Cu}-0.56 \mathrm{at} \% \mathrm{Al}$ 合 金のクリープ速度とセル壁内の平均転位間隔 との関係 ${ }^{(29)}$.

\section{（6）定常状態を破ったあとのせん移挙動}

これまで述べたことは主として定常段階でのことであ るが，ここで $\dot{\varepsilon}_{S}$ にいて少し考えてみよう．II型の場 合には文字通り回復律速ということで $\dot{\varepsilon}_{S}$ は転位の消隇 (回復) 速度 $\dot{\rho}^{-1}$ によって記述できる.I型の場合でも定 常段階では単位時間に転位シンクに流入する転位の数と そこで消隇する転位の数はつり合っているはずで, $\dot{\varepsilon}_{S}$ は やはり开型と同じ型の式で記述できることになる ${ }^{(30)}$. したがって定常段階に注目する限り，両型の区別ができ ない場合もあり得る。そのため定常段階でクリープ条件 に変化を与光，その後に現われるせん移挙動をしらべて I，II型の判別を行うことが考兄れるが，その二, 三 の方法についてみてみよう。

その 1 つは定常クリープ途中で応力緩和試験を行うも のである。すなわち実験的に得られる応力ー時間曲線の 緩和試験開始直後における接線の傾きから応力変化速 度, $\dot{\sigma}_{r o}$,を求め, 試験機系の弾性率, $K$, を用いてそれを

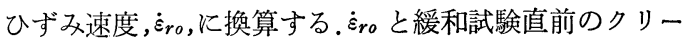
プ速度, $\dot{\varepsilon}_{c}$,との比をとり $\dot{\varepsilon}_{r o} / \dot{\varepsilon}_{c} \simeq 1$ あるいは $\dot{\varepsilon}_{r o} / \dot{\varepsilon}_{c}<1$ の 場合をそれぞれI，而型と判定する(25)，表 1 は高温引 張りによる定常変形中の测定結果の一例で(28)これから も $\alpha$ 鉄はII型, Fe-Mo 合金はI型であると結論され る。

表 $1 \dot{\varepsilon}_{r o} / \dot{\varepsilon}$ のひずみ速度, $\dot{\varepsilon}$, 依存性 ${ }^{(28)}$.

\begin{tabular}{|c|c|c|}
\hline & $\alpha$ 鉄 & $\mathrm{Fe}-3.5$ at $\% \mathrm{Mo}$ \\
\hline$\dot{\varepsilon} / 10^{-4} \mathrm{~s}^{-1}$ 温度/K & 973 & 1123 \\
\hline $\begin{array}{r}\sim 0.5 \\
\sim 1.3 \\
\sim 2.5 \\
\sim 5.0\end{array}$ & $\begin{array}{l}0.59 \\
0.55 \\
0 . \overline{35}\end{array}$ & $\begin{array}{l}0.90 \\
1.15 \\
0.97 \\
0.92\end{array}$ \\
\hline 平均 & $0.49 \pm 0.10$ & $0.98 \pm 0.11$ \\
\hline
\end{tabular}


つぎの方法は定常クリープ中に応力を急変してその後 のせん移挙動をしらべるものである。この場合 2. (2)で 述べたと同様の挙動が期待されるので, 応力を急増した ときに瞬間塑珄ひずみがみられるかどらか ${ }^{(31)}$ ，その後 のせん移クリープ曲線が S字型あるいは通常型を示すか (32)(33)をみることによりI，II型の判別ができる。図 10 は $\Delta \sigma$ だけ応力を急増，急減したときの瞬間伸び, $\Delta l_{+}$, 瞬間縮み, $\Delta l_{-}$,を $\Delta \sigma$ の関数として示したものである ${ }^{(34)}$. I 型の $\mathrm{Al}-\mathrm{Mg}$ 合金では $\Delta l_{+} \simeq \Delta l_{-}$で瞬間塑性ひずみがみ られないのに対して，开型のアルミニウムでは $\Delta \sigma$ と共 に $\Delta l_{+}-\Delta l_{-}$, 寸なわち応力急増後の瞬間塑性ひずみが大 きくなり，両者が対照的な結果を示すことがわかる.

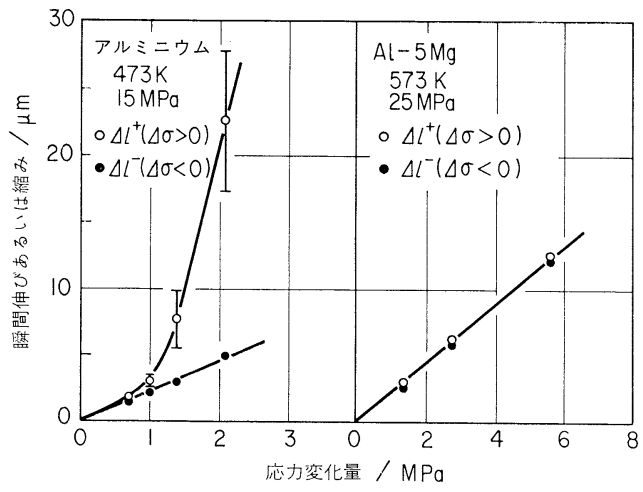

図 10 定常クリープ中に $\Delta \sigma$ だけ応力を急変したと きの瞬間伸びあるいは縮み ${ }^{(34)}$.

(7) 小 括

この章では典型的な高温クリープ挙動としてのI， II 型の特徵やその判別法などを中心に述べてきた。紹介し た例は二，三のものを除いては両者の区别がはっきりと したものであったが，実際は種々の合金に打いてすっき りと区別できない場合も少なくない.

すなわち先に述べた Al-2.2 at\% $\mathrm{Mg}$ 合金は $\dot{\varepsilon}_{r o} / \dot{\varepsilon}_{c} \simeq$ 1 である ${ }^{(4)}$ 上, 内部応力の值や応力急変後の瞬間ひずみ 扣よびせん移クリープ挙動などからはI型と判定され る(35) にもかかわらず，汪ぼ 5 に近い $n$ の值が得られて いる。また Cu-10.4 at\% Al 合金でも $n \simeq 5^{(36)}$ である にもかかわらず，応力急変試験の 結果は $\Delta l_{+} \simeq \Delta l_{\text {_ とな }}$ って転位は粘性連動をしていることを示唆する(37)。 らに $\mathrm{Fe}-1.8$ at\% Mo 合金でも応力急増後瞬間塑性ひ ずみが現われず，せん移クリープ曲線は S 字型を描く(38) ほか, $\sigma_{i}$ の值 ${ }^{(39)}$ からも転位の粘性運動が 結論されるに もかかわらず， $n \simeq 4$ で明らかに 3 より大きい值を示し， またクリープ後の組織にセル形成 ${ }^{(39)}$ がみられる。

このようにそれぞれの判定法によって相反する結果が 得られる場合も少なくないので, 総合的な判断が必要か と思われる。 また応力急変後のせん移挙動を解釈するた
めには，非弾性ひずみを考慮に入れることが必要である との指摘もある ${ }^{(40)}$ が，一層詳細な検討が望まれる。

\section{3．結晶粒界すべりと転位挙動}

\section{（1）結晶粒界すべり}

金属材料は一般に多結晶体のかたちで利用されている が，高温変形中には結晶粒界を境として双方の結晶粒が 相対的に変位するいわゆる結晶粒界すべり(以下粒界す ベりといら)を扎こすのが特徵である(41)．粒界すべりは 応力緩和機構の 1 つとしてひずみの発生に寄与する(42) が，高温粒界破壊にも重要な役割を果している(43)ので， 古くから多くの研究がなされている。

一方, 最近粒界の構造が実験的, 理論的に解明されて きて ${ }^{(44)}$ ，それと共に粒界に関係のある機械的性質 ${ }^{(45)}$ や

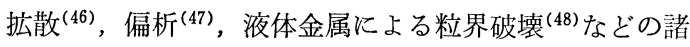
現象が粒界の構造と密接に関連することが明らかになっ てきた，粒界すべりも例外ではないと思われるが，この 現象を粒界構造と結びつけ粒界すべりの微視的機構を究 明しようとする研究が行われるよらになってきた。

これまでの研究によると粒界すべり量は粒界方位差に 依存し，とくに $\sum$ 值の小さい対応粒界 ${ }^{(44)}$ ではそれが著 しく小さい(49)〜(52). また粒界すべりは結晶粒の変形と密 接に関連していることから (53)(54), 結晶変形に関与した 格子転位が粒界に到達したのち，それがそのままあるい は粒界転位に分解して ${ }^{(55) \sim(60)}$ 粒界面上を運動するけこと によって，粒界すべりが生じるというモデルが提案され ている(61) (66). この方面に関するわれわれの研究はまだ 緒についたばかりであるが，つぎにその二，三を紹介し よう.

まず図 11 のように試料表面に垂直な[10 $\overline{1} 0]$ 軸周りの 対称傾角粒界を引張軸に対して $45^{\circ}$ の方向にもつ巫鉛双 結晶での結果 ${ }^{(67)}$ を述べる。図 12 内に示す条件下での粒 界すべり量と傾角, $\theta$, との関係からわかるように小傾角 粒界と傾角 $55^{\circ}$ 付近の粒界での粒界すべり量は小さい. $55^{\circ}$ 付近には $\sum 9$ の近似対応粒界の存在が指摘されてい る(68)ことから，粒界すべりは規則粒界けたでは扢こりにく いことを示す結果であると思われる。

亜鉛双結晶を用いたのは HCP においては一般にすべ りは底面すべりに限定され，したがって結晶変形と粒界

† 結晶内を運動する転位(格子転位)のバーガース． ベクトルは一般には粒界面上にないため，粒界面 上の運動にはすべりと上昇運動が同時に抗こる必 要がある。

† 双方の結晶粒方位が対応方位関係から少しずれて も，粒界に転位を導入すれば双方の原子配列をう まくつなぎ合わすことができる。これす広義の対 応粒界と考兄られ，これらと小角度粒界とを総称 して規則粒界，その他の粒界をランダム粒界と呼 ぶことにする。 


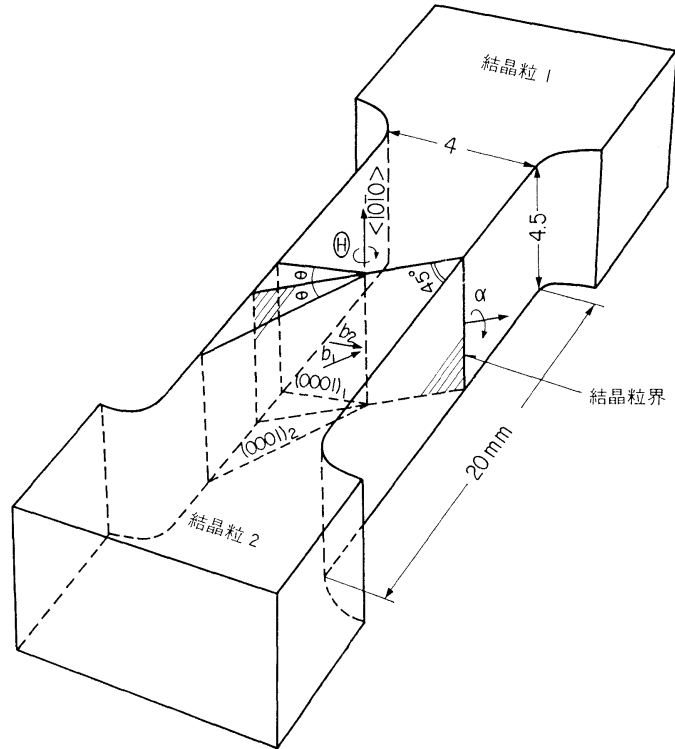

図 11 [10 $\overline{1} 0]$ 軸周りの対称傾角粒界をもつ亜鉛双 結晶試料 ${ }^{(67)}$.

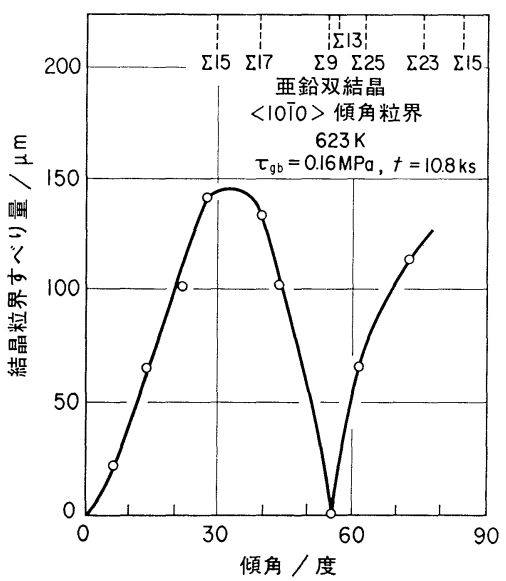

図 12 [10 10$]$ 対称傾角粒界をもつ画鉛双結晶にお ける結晶粒界すべり量の傾角依存性 ${ }^{(67)}$.

すべりの関係をしらべるのに便利なためである，図 11 の幾何学的関係を考学ると，与えられた応力下での結晶 変形によって単位時間に粒界に達する格子転位の数が評 価でき，それらの粓界面上の運動によって生ずる粒界す べり速度が計算できる。このモデル計算からの予想と実 測值の傾角依存性がよく合うことは(67)，粒界すべりに 対する格子転位モデルを支持するものと考光られる。

\section{（2）結晶粒界すべりのその他の特徵}

図 13 のように $[11 \overline{2} 0]$ 軸周りの対称傾角粒界をるつ亜 鉛双結晶でも粒界すべりの傾角依存性をしらべた ${ }^{(69)}$. この場合は $\theta \simeq 15^{\circ}$ 付近までは活とんど粒界すべりを打 こさなかった。また $\theta \simeq 49.5^{\circ}$ 近くに $\Sigma 17$ の近似対応粒 界の存在が指摘されている( ${ }^{(68)}$ が，この傾角近くの粒界
では粒界すべりが小さくなる傾向を示した。これらは 3. (1)の結果同様，規則粒界では粒界すべりが扰こりに くいことを示している。

つぎに特徵的なことは図からわかるように表面 A,B で測定された粒界すべり量が著しく異なることである。

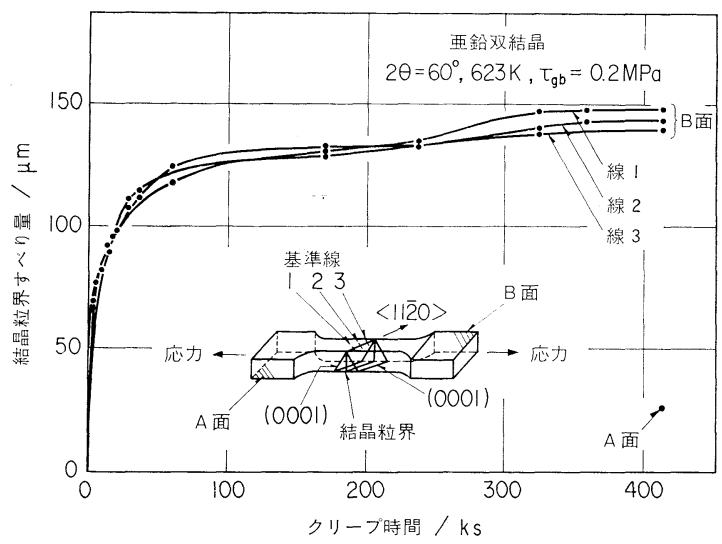

図 13 [11 $\overline{2} 0]$ 対称傾角粒界をもつ业鉛双結晶に拈 ける結晶粒界すべり量の時間変化 ${ }^{(69)}$.
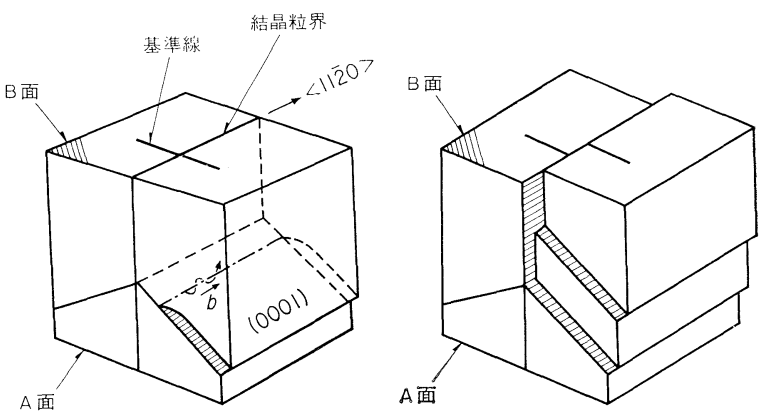

図 14 [11200]対称傾角粒界をもつ覀鉛双結晶に和ける結 晶粒界すべりのモデル表示 ${ }^{(69)}$.

この双結晶では図 14 からわかるように底面すべりのら せん転位が粒界に到達することになるので，結果的には 図のように粒界すべりを扣こすことになる。したがって 表面 Bで観察される粒界すべり量が大きくなる。この結 果も格子転位モデルを支持するものである。

\section{（3）結晶粒界すべりと転位}

粒界すべり挙動をしらべた粒界の構造を透過電子顕微 鏡観察すれば，粒界すべりの微視的機構を推察するよす がが得られるものと期待される。つぎにアルミニウムで の結果 ${ }^{(70)}$ を述べる。図 15 は粒界すべり量の時間的変化 の例であるが，粒界すべりは時間と共に和こりにくくな っている。これは粒界すべり硬化と呼ばれているが，規 則粒界の方が硬化が大きく，また初期の粒界すべり速度 る小さいことがわかる。一方粒界すべり量はクリープひ ずみに比例する(53)(54)ことが示されているが，クリープ 


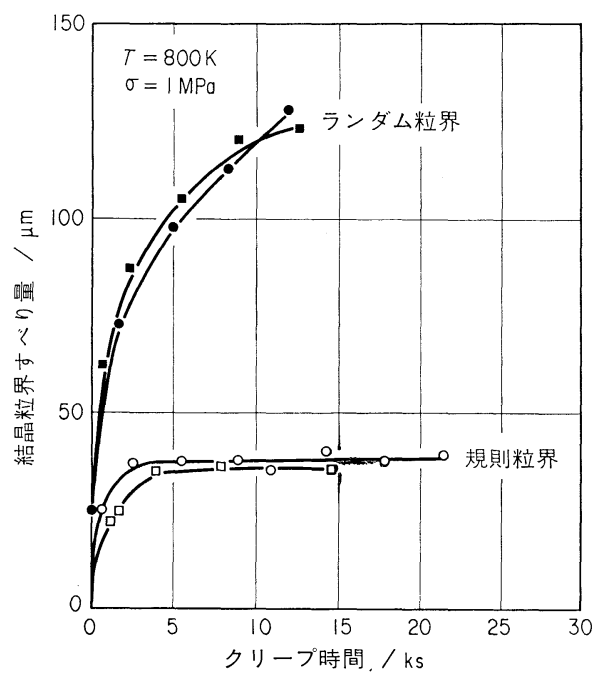

図 15 アルミニウム粗大結晶粒試料に和ける結晶 粒界すべり曲線 ${ }^{(70)}$.

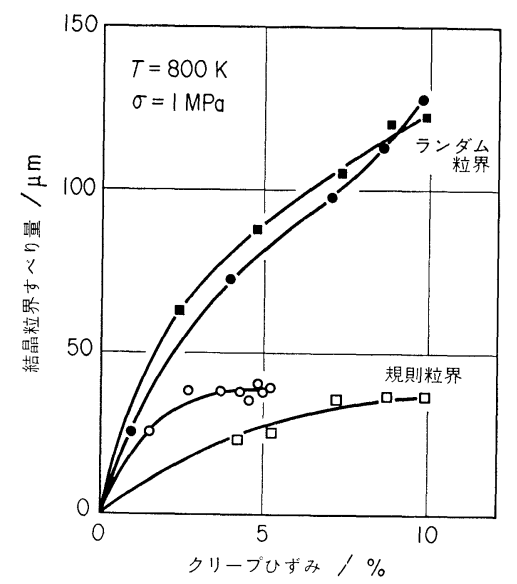

図 16 アルミニウム粗大結晶粒試料の結晶粒界す べり量のクリープひずみ依存性 ${ }^{(70)}$.

ひずみの大きいところまで測定してみると，図 16 のよ らに両者の関係は決して直線的にはならない.このこと は粒界すべり硬化が結晶粒の変形に伴っておこる加工硬 化によって単位時間に粒界に到達する格子転位の数が減 少することによるばかりでなく，それら転位の粒界面上 での運動そのものもクリープひずみと共に困難になるた めであることを示唆している。したがって3.(2)で述べ たわれわれのモデル計算 ${ }^{(67)}$ も，このことを考慮してさ らに発展させる必要があろう。

ところで格子転位が粒界面上を運動する場合，実際に は格子転位が粒界転位に分解するというかたちで粒界に 吸収されたのち，その粒界転位が粒界面上を運動すると いう 2 つの素過程を考える考え方が有力である．前述の 亜鉛双結晶の結果をも含めて，規則粒界で粒界すべりが 扣こりにくいことは，この吸収過程が困難なためである
ことが推察される。つぎにそれを支持する透過電子顕微 鏡観察結果を述べる。

これによると大きい粒界すべりを抗こしたランダム粒 界では, 回折条件を変えて観察しても粒界縞模様以外の コントラストがみられなかったのに対して, 粒界すべり が扢こりにくかった規則粒界面上にはほとんどの場合転 位像が観察された ${ }^{(70)}$. これらの結果は粒界転位のバー ガース・ベクトルは小さいため，それへの分解がおこる と転位コントラストを示しにくいこと，扎よび規則粒界 では吸収が困難のため未分解の格子転位が残っている可 能性があることを考えるとよく理解される。またこの転 位の存在が規則粒界で粒界すべり硬化が大きい一因を与 えているものと考えられる。

\section{(4) 小 括}

以上述べたことを総括すると, 粒界すべりは結晶変形 々密接に関係していて, それは格子転位の粒界転位への 分解拉よびその粒界転位の粒界面上での連動といら過程 を経て持こるとの考え方が妥当であると結論できょう. しかし提唱されているモデルはまだ単純すぎて，多くの 結果を矛盾なく説明するにはさらにモデルを発展させて いく必要がある。そのためにも系統的なデータの集積が 望まれる。また粒界すべりが粒界構造依存性をもつ以 上, それと密接な関連をるつ高温破壞現像も粒界構造に 大いに支配されるであろうことが予想される。この方面 の系統的な研究がまたれる所以である.

\section{4.おわりに}

高温クリープおよび粒界すべりについて述べたが，わ れわれの研究の紹介にしぼったため内容が大分偏ったも のになったことを祘びする，終りに今回の栄誉は研究 室の諸兄および研究室を巣立っていった学生諸君の絶ゆ まざる努力の結果にほかならないことを記して, 感謝に かえたいと思う。

\section{文献}

（1）たとえば,F.Garofalo: Fundamentals of Creep and Creep-Rupture in Metals, Macmillan, (1965) .

(2) J.E.Bird, A.K.Mukherjee and J.E.Dorn : Quantitative Relation between Properties and Microstructure, ed.by D.G.Brandon and A. Rosen, (1969) , 255.

(3) O.D.Sherby and P.M.Burke : Progress in Mat. Sci., 13 (1968), 323.

(4) H.Oikawa, K.Sugawara and S.Karashima: Scripta Met., 10(1976), 885.

（5）堀内 良, 大塚正久:日本金属学会誌, 35 (1971), 406.

（6）吉永日出男, 当摩 建, 諸住正太郎 : 同上, 38 (1974), 826. 
(7) H.Oikawa, N.Matsuno and S.Karashima : Metal Sci., 9(1975), 209.

(8) J.Weertman : J.Appl. Phys., 26(1955), 1213 ; $28(1957), 362$.

(9) C.R.Barrett and W. D. Nix : Acta Met., 13 (1965) , 1247.

(10) S.K.Mitra and D.McLean : Proc. Roy. Soc., 295(1966), 288.

(11) R. Lagneborg: Metal.Sci. J., 3 (1969), 161; 6 (1972), 127

(12) W. Blum : phys. stat. sol., (b) 45(1971), 561.

(13) J.R.Spingarn and W.D.Nix : Acta Met., 27 (1979), 171.

(14) H.Oikawa, N.Kuriyama, D.Mizukoshi and S. Karashima : Mater. Sci. Eng., 29(1977), 131.

(15) T.Hasegawa, Y.Ikeuchi and S.Karashima: Metal Sci. J., 6(1972), 78.

(16) H. Oikawa, M. Maeda and S. Karashima : Scripta Met., 6(1972), 339.

（17）松野伸男, 及川洪, 辛島誠一：日本金属学会 誌, 33 (1974) , 1071.

(18) T.Hasegawa, H.Sato and S.Karashima : Trans. JIM, $11(1970), 231$.

(19) 松野伸男 : 東北大学修士論文, (1974).

(20) T.Hasegawa,S.Karashima and R.Hasegawa: Met. Trans., 2(1971) , 1449.

(21) A.Orlová and J.Čadek : Phil.Mag., 28 (1973), 891.

(22) T.Hasegawa, R.Hasegawa and S.Karashima: Trans. JIM, $11(1970), 101$

(23) S. Karashima, T. Iikubo and H. Oikawa : ibid., 13(1972) , 176.

(24) 飯久保知人：東北大学博士論文, (1973).

(25) 阿部勝憲, 吉永日出男, 諸住正太郎：日本金属学 会誌, 40(1976), 393.

（26）内部応力測定についてはたとえば，長谷川 正， 及川 洪：日本金属学会会報, 11(1972)，192.

(27) 当摩 建, 吉永日出男, 諸住正太郎 : 日本金属学 会誌, 39(1975), 621 .

(28) H.Oikawa, K.Ichihashi and S.Karashima : Scripta Met., 10(1976), 143.

(29) T.Hasegawa, S.Karashima and Y.Ikeuchi: Acta Met., 21 (1973), 887.

(30) 丸山公一, 辛島誠一, 及川 洪：日本金属学会講 演概要, $(1978 \cdot 10$ 月), 169.

(31) K. Maruyama and S. Karashima : Trans. JIM, $16(1975), 671$

(32) R.Horiuchi and M.Otsuka : ibid., 13(1972), 284.

(33) 及川 洪, 佐伯真事, 辛島誠一：鉄と鋼，65 (1979), 843.

(34) H. Oikawa and K. Sugawara : Scripta Met., $12(1978), 85$.

(35) H.Oikawa, K.Sugawara and S.Karashima : Trans. JIM, 19(1978), 611.

(36) M. Pahutová, J. Ćadek and P. Ryš : Phil. Mag., 22 (1970) , 1175.

(37) H.Oikawa : ibid., A 37 (1978), 707.

(38) H.Oikawa, D.Mizukoshi and S.Karashima: Met. Trans., $9 \mathbf{A}(1978), 1281$.

(39) D.Mizukoshi, H.Oikawa and S.Karashima: Trans. ISIJ, 18(1978), 696.
（40）安田 顕, 及川 洪, 辛島誠一：日本金属学会春 期大会で講演発表, (1979·4 月)。

(41) たとえば, H.Conrad : Mechanical Behavior of Materials at Elevated Temperatures, McGrawHill, (1961) , 218.

(42) たとえば, D.McLean : Mechanical Properties of Metals, John-Wiley and Sons, (1962), 303.

（43）たとえば, 渡辺忠雄：日本金属学会会報，12 (1973) , 883.

（44）たとえば，石田洋一：同上，9(1970)，156。

(45) J.P.Hirth : Met.Trans., 3 (1972), 3047.

(46) 古山直行, 石田洋一, 清水 筆: 日本金属学会講 演概要, (1978.4 月), 184 .

(47) T.Watanabe, T.Murakami and S.Karashima: Scripta Met., 12 (1978), 361.

（48）渡辺忠雄，嶋 誠之，辛島誠一：日本金属学会講 演概要, (1978·10月), 93; (1979.4月), 107.

(49) M.Biscondi and C.Goux : Mém. Sci. Rev. Mét., 65 (1968) , 167.

(50) P.Lagarde and M.Biscondi : ibid., 71 (1974), 121.

(51) B.Michaut, A.Silvent and G.Sainfort : ibid., 71 (1974), 527.

(52) P.Largarde and M.Biscondi : Can. Met. Quart., $13(1975), 245$.

(53) D.McLean and M.R.Farmer : J.Inst.Metals, $85(1956 / 57), 41$.

(54) T.Watanabe and P.D.Davies : Phil. Mag., A37 (1978), 649.

(55) W.Bollmann, B.Michaut and G.Sainfort: phys. stat. sol., (a) 13(1972), 637.

(56) R.C.Pond and D.A.Smith : Phil. Mag., 36 (1977) , 353.

(57) R.C.Pond, D.A.Smith and P.W.Southerden: ibid., A37 (1978) , 27.

(58) R.C.Pond : Proc.Roy.Soc., A357(1977) , 471.

(59) P.R.Howell, A.R.Jones, A.Horsewell and B.Ralph : Phil. Mag., 31 (1976), 21.

(60) P.R.Howell, J.O.Nilsson and G.L.Dunlop : ibid., A38 (1978), 39.

(61) Y.Ishida and D.McLean : Metal Sci. J., 1 (1967), 171

(62) D.McLean : Phil.Mag., 23 (1971), 467.

(63) G.R.Kegg, C.A.P.Horton and J.M.Silcock : ibid., 27 (1973) , 1041.

(64) C.A.P.Horton, J.M.Silcock and G.R.Kegg: phys.stat.sol., (a) 26 (1974), 215.

(65) R.S.Gates : Acta Met., 2(1973), 855 ; Scripta Met., 8(1974), 55 .

(66) R.C.Gifkins : Met.Trans., 7A(1976), 1225.

(67) T.Watanabe, M. Yamada, S.Shima and S. Karashima : Phil.Mag., 印刷中.

(68) G.A. Bruggeman, G.H. Bishop and W.H. Hartt: Nature and Behavior of Grain Boundaries, ed. by Hsun $\mathrm{Hu}$, Plenum Press, (1972), 83.

(69) T.Watanabe, N. Kuriyama and S. Karashima: Proc. 4th Int. Conf. on the Strength of Metals and Alloys, (1976), 383.

(70) 粉川博之：東北大学博士論文, (1979). 